\title{
СТИЛЕТВІРНИЙ ПОТЕНЦІАЛ ЗАСОБІВ МУЗИКАЛЬНОСТІ РАННЬОЇ ЛІРИКИ ПАВЛА ТИЧИНИ
}

Мішеніна Т. М. Стилетвірний потенціал засобів музикальності ранньої лірики Павла Тичини.

У статті розкрито стилетвірний потенціал зображальних засобів музикальності в українській мові. 3'ясовано, що звуковий символізм передбачає закономірний недовільний фонетично мотивований зв'язок між музичним терміном і покладеною в основу номінації сугестивною фоновою звуковою ознакою денотата (мотивом): музичний звук, ритм, акорд, музичний інструмент, мелодія тощо.

Ключові слова: зображальні засоби музикальності, кларнетизм, звуковий образ, музичний термін.

Мишенина Т. М. Стилеобразующий потенциал средств музыкальности ранней лирики Павла Тычины

Аннотация. В статье раскрыт стилеобразующий потенциал изобразительных средств музыкальности в украинском языке. Исследовано, что звуковой символизм предусматривает закономерный не непосредственную фонетическую мотивированную связь между музыкальным термином и заложенным в основу номинации сугестивным звуковым признаком денотата (мотивом): музыкальный звук, ритм, аккорд, музыкальный инструмент, мелодия и т.п.

Ключевые слова: изобразительные средства музыкальности, кларнетизм, звуковой образ, музыкальный термин.

Mishenina T.M. Trailblazing musical potential of the early lyrics of Paul Tychyna

Abstract. The article discloses a trailblazing potential of pictorial means of musicality in the Ukrainian language. It explores the symbolism that provides a natural sound not directly motivated phonetic connection between music and the term laid the basis for the nomination convicing audible indication denotation (the motive): musical sound, rhythm, chord, instrument, melody, etc.

Key words: graphic arts musicality, klarinets', sound image, a musical term.

Своєрідність, підкреслена відчутність звукової форми створює виразність художньо-мовленнєвої тканини. Виразність вияву форми повідомлення не пов'язується лише з мовленнєвою його функцією: загалом виразність спирається на варіативність, тобто можливість різного оформлення приблизно одного змісту, який складає об'єктивну, загальну основу повідомлення.

На сучасному етапі розвитку лінгвістики існує чимало цінних 
спостережень, присвячених звукозображанню, однак свої повідомлення науковці переважно грунтували на обмеженому фактичному матеріалі, недосконалій методиці дослідження й абсолютизації принципу звуконаслідування, а також принципу побудови синестезійних образів, побудованих на звукових відчуттях.

Звукову будову української мови, уплив звукового ладу на вираження додаткових семантичних компонентів досліджували I. Білодід, М. Горелікова, М. Голянич, Н. Дащенко, І. Кочан, Ю. Маленовський, Л. Мацько, О.Снітко, Н. Сологуб, В. Чабаненко та інші $[1 ; 2 ; 3 ; 4 ; 7]$.

Звукосимволізм в аспекті національної культури не знайшов належного відображення в наукових розвідках лінгвістів. Залишилися поза увагою зображальні засоби музикальності, які спрямовують на асоціативну рефлексію фонового музичного фону зображувальної дійсності; функціональне навантаження синтестезійних образів поетичного тексту взагалі, певної стильової течії - зокрема. Мелодійність, злагодженість поетичної матерії має також сугестивну функцію - вплив на емоційну сферу людини через звукову синестезію.

Мова ранньої поезії Павла Тичини з позиції звукозображальності як стильової якості кларнетизму об’єктом спеціального дослідження не була.

Мета публікації - 3’ясувати роль зображальних засобів музикальності у створенні сугестивних звукових образів поетичного мовлення Павла Тичини.

Основою семантики зображальних засобів музикальності $є$ принцип недовільності мовного знака, а також принципи відображення, детермінізму, цілісності, багатоплановості. Властивість, на основі якої конструюється система звукових образів, $є$ звукозображальність, або фонетична (примарна) умотивованість.

Аналізуючи звукові комплекси й окремі звуки, рефлексовані фоновими знаннями про звукову якість як іманентну для аналізованих об'єктів, за ми розмежовуємо типи зображальних засобів музикальності за семантичними параметрами звукообразності, а також відповідно до теорії музики.

I. Пісня. Привертає увагу музична орнаментика художніх образів, яка полягає в посиленні експресії основної мелодії, демонстрації віртуозних можливостей виконавця:

(C) Т. М. Мішеніна, 2015. 
- людина: Я стежу за хмарками, / Ловлю їх світлий сум. / Ах, серце ж те все в пісню / Чудову переллє! [8, с. 130]; Цвітуть в піснях україночки, / Дзвіночки срібляні. / Душею чорнобривочки / Струнчасто-осяйні! [8, с. 139]; Гей, вдарте в струни, кобзарі, । Натхніть серия піснями! [8, с. 140]; Мені все сниться: сонце, співи, / $i$ Ви, $i$ день весняний, - $i$ от я з Вами вже знайома, / поете мій коханий [8, с. 74];

- спільнота: Вітай же нас ти з сонцем, голубами, Я дужий народ! - з сонцем, голубами. Вітай нас рідними піснями! Я молодий! Молодий! [8, с. 55];

- фітоніми: Колисково, колоски! : удень [8, с. 32] - естетичний ефект досягається засобом використання від субстантивного прислівника способу дії (колискова пісня); оксюморонне слововживання актуалізує семантичний компонент «заспокійливість», «елегійність», «тиша»;

- орнітоніми: Іще пташки в дзвінких піснях блакитний день купають [8, с. 25];

- просторові поняття: Співає стежка На город. Гарбуз під парасольками Про сонще думає [8, с. 30];

- природа: I слухає мій сум природа. Люба. Щира. Крізь плач, крізь сміх. Вона сама - иарівна мила - Не раз свій смуток хоронила $B$ самій собі, в піснях своїх [8, с. 23];

- складник внутрішнього світу - конструктивна / деструктивна емоція: Припливеш, приплинеш - Сум росте, мов колос: 3 піснею про сонце! - Сумно, сам я, світлий сон... [8, с. 20]; Сум серие тисне: сонце! пісне! - В душі я славлю - вас я славлю! - В душі я славлю світлий парус, бо в мене в серизі сум [8, с. 11].

Уживання художніх означень дозволяє розширити структурносемантичний діапазон оксиморонних поєднань, які за своєю природою $\epsilon$ суперечливими в тому сенсі, що одному об'єкту приписуються властивості «бути $\underline{a}$ » і «бути $\underline{\mu e-a » . ~ Б у к в а л ь н и и ̆ ~ с м и с л ~ м і с т и т ь ~ з а г а д к у, ~}$ a метафоричний - iї розв'язання. При цьому поняття напруги й суперечності орієнтовані на формальний бік загадки, на те, що можна назвати семантичним викликом. Інтерес становить нове узгодження, нове поняття, що виникає у відповідь на такий семантичний виклик.

Оксиморонне розв'язання в художньому мовленні здатне розвиватися в ліричний сюжет, виконуючи роль структурно- 
композиційної основи твору, становлячи в такому разі стилетвірний чинник: Пишу до Вас, бо так схотіла. Скажіть мені: кому потрібні рахітичні оті сонети та пісні? [8, с. 75].

Оригінальним авторським рішенням Павла Тичини $\epsilon$ використання в символічному значенні музичних термінів гімн, молитва.

Гімн - різні за змістом урочисті пісні, які мають витоками піснімольби / моління до богів [с. 136].

Молитва становить звернення до божества; своєрідний діалог 3 надприродним світом. Панмузична стихія ранньої поезії Павла Тичини засвідчує художнє переосмислення молитви - прагнення заступу правдивості вищими надістотами; поклоніння гармонії природи; узаємозв'язку внутрішнього і зовнішнього світу: Він був мов жрецьь, сп'янілий від молитви - Наш Київ, - Який моливсь за всю Вкраїну - Прекрасний Київ - буря! [8, с. 52]; Пливуть молитви угорі. (Вернися з сміхом-дзвоном!) Спадає лист на вівтарі - (Кучерявим дзвоном...) [8, с. 18]; Життя моє - молитва / Всевладниці Красі, / Горіння - розцвітання / В огні квіток-думок [8, с. 130].

У функції прикладки лексема молитва формує символ, який конституюється на християнських традиціях; спостерігаємо накладання семем «провісник миру, благодаті» i «звернення iз високоморальними намірами»: Бог заспіває. Падають / Зерна / Кришталевої музики. / 3 глибин Вічності падають зерна / В душу. / I там, у храмі душі, / Над яким у недосяжній високості в'ються голуби-молитви [8, с. 52].

Язичницький складник художнього символу гімн інтерпретується також і негативно, як спростування давніх, забобонних уявлень про перевагу надприродних істот над вибором людини взагалі, засудження немилосердного ставлення до людини - зокрема: За частоколом зелений гімн. Зоставайтеся, люди, 3 своӥми божками! [8, с. 30].

Павло Тичина переосмислює поняття гімну як розуміння гармонії, взаємозв'язку складників навколишньої дійсності; досягнення найвищої майстерності в певній діяльності: Найглибший, найвеличніший $і$ разом з тим / найпростіший зміст, укладений на двох-трьох / нотах, - оче й є справжнній гімн [8, с. 110].

Воля розуміється поетом як гімн природному поступові людства: Візьмім, візьмімо на гострі леза! Всім краям - / Марсельєза! [с. 73]; () Т. М. Мішеніна, 2015. 
Будьте безумні - не зимні. Нові, по нові марсельєзи! Направо, наліво мечі-ставте дієзи в ключі! [8, с. 61].

Експресивний ефект досягається використанням авторського неологізму - дієприкметника, утвореного від відсубстантивного дієслова, що актуалізує ознаку «набути якості прагнення волі»: Тебе замучили кати... Омарсельєзені світи / взялись жалобою та горем $[8$, c. 85$]$.

II. Музика - мистецтво інтонації, художнє відображення дійсності у звучанні [6, с. 359].

У художньому дискурсі музика спрямована на музичну стихію, створення синтетичних образів задля втілення особливої образної думки, яка асоціює стани i процеси реальності, внутрішніх переживань із слуховими рефлексуваннями.

Автономність музичного образу в кларнетичному поетичному письмі Павла Тичини виявляється насамперед у кореляції iз соціокультурною дійсністю; одночасному відтворенні конкретності відчуття й узагальненості думки. Ефект музикальності досягається шляхом розгортання таких ланцюжків, як прозорість / музика; високість, всеохопність / музика; непізнаність, єдність добра і зла / божественна музика:

- християнська традиџія: Бог заспіває. Падають / Зерна / Кришталевої музики. / 3 глибин Вічності падають зерна / В душу. / I там, у храмі душі, / Над яким у недосяжній високості в'ються голуби-молитви [8, с. 52];

- язичницька традиція (мікро- $і$ макрокосм, ідея їх всеєдності): Ах, небу голубому, / Аx, золотим вітрам - / Повірте, люди, - сонцю / I музиці його! [8, с. 133];

- синкретичне поняття: I бог послав зозулю. - на віку пий музику / муку / випадковий цьього віку потопельнику - Сумно. / Зелена неділя $[8$, c. 45$]$.

Сугестійний вплив музики в художньому мовленні відтворює співвідношення тимчасової природи музичного мистецтва і художньосмислової єдності: Люблю / астрономію / музику / $i$ жінку. / Астрономія воздвигає, / музика оп'яняє, / жінка дивує - / у голосі, у погляді, навіть у посмішиі - / жінка завжди рождає [8, с. 179].

Гармонія Всесвіту поетом розуміється крізь призму «музики сфер», гармонію їх музичного буття: Прокинувсь я - $і$ я вже Ти: Над 
мною, піді мною / Горять світи, біжать світи Музичною рікою $[8$, c. 10$]$.

На окремий розгляд заслуговують мовні конструкції, які створюють музикальний ефект за критерієм міри гучності:

1. Явище природи: Іще й тоді, як над безмежною водою паслися табуни вітрів, - іще й тодi, як гори затряслись, порепалась земля... [8, с. 98]; Інакше плачуть хмари і стогне буйний вітер: / В їх горі щзира крутість і саможертви зміст [с. 125]; Листя падає / Осінь листопадує / По доріжиі, на'дній ніжиі / вітер робить па / вітер / па [8, с. 152]; I я побіг. Над муттю - / то був такий прорив! / На дві октави нижче / шуміло із гори... [8, с. 197]; На стрімчастих скелях, Де орли та хмари, Над могутнім морем, В осяйній блакиті - Гей, там / Розцвітали грози! Розцвітали грози... [8, с. 36].

2. Фітоніми: Ви знаєте, як липа шелестить / У місячні весняні ночі? [8, с. 121]; Шепчуть вітру квітки: гей, в танок! / Повінчайся 3 туманами ночі. / Тихо так опівночі... [8, с. 124]; Гаї иумлять - Я слухаю [8, с. 12]; Я йду, іду - Зворушений. Когось все жду-Співаючи. Співаючи кохаючи / Під тихий шепіт трав голублячий [8, с. 12]; Чорний ліс гуде-стинається [8, с. 145].

3. Орнітоніми: ... спокій сіють / Сріблясті голуби у небесах [8, с. 25]; Ось місяць, зорі, солов'ї... «Я твій»-десь чують дідугани, / А солов'̈! / Та ви вже знаєте, як сплять гаї! [8, с. 121]; А я у гай ходила / по квітку ось яку / а там дерева люлі / $і$ все отак зозулі / ку ку [8, с. 34]; Встали мати, встали й татко: Де ластовенятко? $[8$, c. 16$]$.

4. Комахи: Цвірчіння стопрозоре, / а вітру аніяк [8, с. 200].

5. Астронімний складник: Загримів, заграв, / тупотом пішов- / ковую зелену / кленоклонив день [8, с. 167]; I тільки повно слуху. / I ряснозорна бризь / одглибинилась скрізь / без руху... [8, с. 200]; Уже $i$ Всесвіту не чуть - / лиш тиша ллє і ллє... [8, с. 198]; I настала ніби тиша, / ніби злотне плюскотіння. / Зараз, зараз я побачу, / як рождатиметься сонце [8, с. 204].

6. Синкретичні образи (ефект багатоголосся): За вікном шумлять тополі, / Журавлині ключі... [8, с. 131]; Живі землі живої, / Згадайте ви весну, / Блакитно-ясні бурі / І цвітно-травний шум [8, с. 133]; Квітне сонцее, грас вітер / I Дніпро-ріка [8, с. 140].

Рання лірика Павла Тичини кларнетизує художню дійсність, (C) Т. М. Мішеніна, 2015. 
екстраполюючи суперечність і гармонію світобудови на фоні звукового супроводу, що виявляється у протиставленні / зіставленні / кореляції:

- Тиша - гучність (багатоголосся довкілля): Ромашка? здрастуй! I вона тихо: здрастуй. I згучить земля Як орган [8, с. 31]; Світає... Все спить ще: $і$ небо, $і$ зорі безсилі, Лиш птах десь озвався спросоння ліниво Та темний бовван на козачій могилі Про давнє, минуле кричить мовчазливо [8, с. 26]; Одне одвеснить / друге веслує / а все як море / прибій бій [8, с. 148].

- Імітація стану природи і людини (сміх (радість) - плач (сум, печаль, страждання, туга, роздум): Предки жертви сониңю приносять - I того золотий гомін. Ах той гомін!.. За ним не чути, щуо друг твій каже. Від нього грози, пролітаючи над містом, плачуть, - Бо їх не помічають Гомін золотий! [8, с. 57]; Ридма ридають хвилі, а морю пишуть ріки, / Що води ӥх сміються від сонця і вітрів [8, с. 125]; Там за нивами: Ой одкрий Колос вій! Сміх буде, плач буде Перламутровий... [8, с. 13]; Здаля сміялась струнка тополя. Сліпучі тони - й смутні волошки... [8, с. 35].

- Кореляція емоційного стану і фізичного вияву (сміх (радість) плач (сум, печаль, страждання, туга, роздум): Пливуть молитви угорі. (Вернися з сміхом-дзвоном!) Спадає лист на вівтарі - (Кучерявим дзвоном...) [8, с. 18]; Іоуть! I всі сміються, як вино: I всі співають, як вино: Я -дужий народ, Я молодий [8, с. 55].

- Суголосся стану природи і стану людини: I підняв огонь свої долоні: бурі веселі! - хоче думать туман [8, с. 72]; А хтось кричить: ти рідну стрів! I раптом - небо... шепіт гаю... [8, с. 19]; 3 кохання плакав я, ридав (Над бором хмари муром!) [8, с. 18]; Той плач між нею, мною став - (Мармуровим муром...) [8, с. 18]; Ой ти ранку, любий сонку, / Tреті півні голосні! [8, с. 131]; Десь на дні мого серия / Заплела дивну казку любов. / Я ішов від озерия... Говори, говори, моя мила: / Твоя мова - співучий струмок [8, с. 124].

- Відтворення арітектоніки світобудови: Заплакав дощ... i вщух. Мовчить гора. Мовчить долина. - Господня тінь, - прошепотів полин [8, с. 25]; I дощ заколихався, / перемісило муть. / Грімкі, палкі промови / над морем як у тьму [8, с. 197]; Аx, / нікого так я не люблю, / як вітра вітровіння, / його шляхи, його боління / $i$ землю, / землю свою [8, с. 181]; Вічний, вічний, нерозгаданий, / нерозривний наш, / 
скрізь твоє дихання бурі, скрізь твоя душа [8, с. 201].

- Іманентна риса: Ходить ніч по саду / місячними кроками, / зоряними криками / просіває пітьму [8, с. 202].

- Каузальні відношення (прикмета певної подіі): Ні бога, ні чорта - на бурю! : гей, стійте! Знайдем і в церквах. Знялось гайвороння - на бурю... [8, с. 38]; Ах, ізнов, кохана, Де згучала рана, - Квітне иввітпервоцвіт! [8, с. 15]; На схід сония грають грози - Будуть знову сльози! [8, с. 16].

Синестезійний звуковий образ, за нашим спостереженням, у кларнестійному письмі Павла Тичини переважно вибудовується на основі поєднання спектральних і звукових компонентів, що дозволяє зробити висновок про образотворче спрямування звукових образів ранньої тичининської поезії, унікальний, фольклорно позначений, імажинізм: Здаля сміялась струнка тополя. Сліпучі тони - й смутні волошки... [8, с. 35]; Там за нивами: Ой одкрий Колос вій! Сміх буде, плач буде Перламутровий... [8, с. 13]; Живі землі живої, / Згадайте ви весну, / Блакитно-ясні бурі / І цвітно-травний шум [8, с. 133]; Цвірчіння стопрозоре, / а вітру аніяк [8, с. 200]; Бог заспіває. Падають / Зерна / Кришталевої музики. / 3 глибин Вічності падають зерна / В душу. / I там, у храмі душі, / Над яким у недосяжній високості в'ються голуби-молитви [8, с. 52].

III. Струна - джерело звуку у струнних інструментах; під час коливання струни створюється основний фон і ії частини, що створює обертон [6, с. 526].

У художньому тексті звукові сугестивні асоціації з музичним терміном струна різноманітні:

- музична характеристика фітонімів: Соняшники горять... - сама як струна - Метеликів дуети... - а на лапках мед - [8, с. 31]; Гей, над дорогою стоїь верба, Дзвінкі дощові струни ловить, Все вітами хитає наче сумно мовить: Журба, журба... [8, с. 23];

- музична характеристика астронімів: Отак роки, отак без краю На струнах Вічності перебираю я, одинокая верба [8, с. 23]; $A$ в глибині землі і надо мною - струни, струни... [8, с. 149]; Казало сонце / дивись на соние / мільярди в землю / від нього струн [8, с. 148];

- музична характеристика гідронімів: Над Києвом - золотий гомін, I голуби, і сонце! Внизу - Дніпро торкає струни... [8, с. 51];

- музична характеристика внутрішнього стану: $A$ в мені () Т. М. Мішеніна, 2015. 
(забринів струнний гнів) - Ой, буде ще потопу, $і$ сміху, $i$ вина $[8$, c. 69$]$;

- соціокультурні фонові знання: - Гей, вдарте в струни, кобзарі, / Натхніть серия піснями! [8, с. 140].

Своєрідною є апеляція до танцювальних ритмів, що посилює конотативний значеннєвий компонент «молодість, краса, натхнення»: Ритм. Коли йде дві струнких дівчині - ще й мак / червоний в косах - / - десь далеко! Молоді планети! / Пливуть. Струнчать. Атоми утоми - на світ, / у світ із тьми! Танцюють, куряву збивають... / Сония / стають у коло. А від них майви / по всесвіту всьому. / Дві дівчині $[8$, c. 101$]$.

IV. Гама (звукоряд) - поступове збільшення або зменшення послідовності всіх ступенів ладу, починаючи 3 основного тону [6, с. 124].

Художне відтворення гами становить засіб розвитку музичної гри: Так тихо... В туман загорнувшись, далекі тополі В дущі вигрівають мінорную гаму [8, с. 26]; Ударте у мідь, обезхмарте! Вірте (не лірте!), ідіть, фанфарами крикніть вночі: дієзи, дієзи в ключі! [8, с. 61]

Новаторство ранньої поезії Павла Тичини полягає у відображенні у слові закономірного недовільного фонетично вмотивованого зв'язку між звукоформою i покладеною в основу номінації акустичною ознакою денотата (ідіофони, різні види руху, процеси, явища природи, фізіологічні та емоційні стани людини).

Усе це естетизує й інтимізує поетичні рядки, які за звучанням і смислом охоплюють якнайширший простір для відтворення дійсності: від пісенної форми, відтворення глибин ліричного переживання до символічних образів крізь призму художніх засобів музикальності кларнестійного письма.

Різноаспектність, багатоаспектність смислових інтерпретацій звукового образу з позиції лінгвоаналізу засвідчуе поліфонічне тлумачення автором ідеї сили народи, краси рідної землі, людських переживань. У цьому і полягає смислова доцільність, оригінальність звукової тканини поетичного мовлення раннього Павла Тичини, мистецтво поетичної творчості.

Сугестивна функція засобів музикальності художньої кларнестійної тканини Павла Тичини переконує в тому, що 
аналізований напрям уможливлює поєднання конкретно-чуттєвої і морально-етичної природи, дає змогу поєднати фольклорні і модерні традиції у відтворенні внутрішнього світу людини, філософське розуміння й переосмислення соціокультурної дійсності в історичному перебігові їі історії.

\section{Література}

1. Бандура О. М. Теорія літератури / О. М. Бандура. - К. : Рад. шк., 1969. - 286 с.

2. Голянич М. I. Внутрішня форма слова і художній текст / М. I. Голянич. Коломия : Вік, 1977. - 180 с.

3. Гореликова М. И. Лингвистический анализ художественного текста / М. И. Гореликова, Д. И. Магомедова. - М. : Русский язык, 1983. - 124 с.

4. Качуровський I. Фоніка / І. Качуровський. - К. : Либідь, 1994. - 168 с.

5. Літературознавчий словник-довідник / Р. Т. Гром'як, Ю. І. Ковалів та ін. - К. : ВЦ «Академія», 1997. - $752 \mathrm{c.}$

6. Музыкальный энциклопедический словарь / гл. ред. Г. В. Келдыш. - М. : Советская энциклопедия, 1990. $-672 \mathrm{c}$.

7. Сучасна українська літературна мова: Стилістика / за ред. І. К. Білодіда. - К. : Наукова думка, 1973. - 582 с.

8. Тичина П. Г. Десь на дні мого серця : Поезії / П. Г. Тичина ; упоряд. Головко Д. А. - К. : Рад. письменник, 1991. - 221 с.

Стаття надійшла до редакиії 27.03.2015 p. 